\title{
スキー板の弾性パラメータの同定に関する研究*
}

\author{
細川健 治*1, 佐 藤悠 有*2, 坂 田 敏 行*3
}

\section{Study on Identification of Elastic Parameters for Skis}

\author{
Kenji HOSOKAWA**, Yu SATO and Toshiyuki SAKATA \\ ${ }^{* 4}$ Department of Mechanical Engineering, Chubu University, \\ 1200 Matsumotocho, Kasugai-shi, Aichi, 487-8501 Japan
}

\begin{abstract}
The elastic parameters of skis are essential for simulation on skiing. Generally, the elastic parameters of skis have not been reported. Also, the elastic parameters of skis are difficult to determine by either theoretical and experimental approach. Therefore, an inverse analysis method to identify equivalent elastic parameters of skis is very important. In the identification method, mainly, the experimental modal analysis technique, the finite element method and the sensitivity analysis method are used. First, by applying the experimental modal analysis technique to a ski with free boundary conditions, natural frequencies and mode shapes are obtained. Secondly, from the obtained natural frequencies and mode shapes, the equivalent elastic parameters of the ski are identified numerically. Finally, to justify the application of this approach, the bending stiffiness and twisting stiffness in longitudinal direction calculated by the obtained equivalent elastic parameters of the ski are compared with those obtained by the other experimental method.
\end{abstract}

Key Words : Free Vibration, Inverse Problem, Identification, Elastic Parameters, Finite Element Method, Experimental Modal Analysis, Ski

\section{1. 緒}

毎年, 多種多様なスキー板が市販されているが, ス キー板の設計開発は主に設計者の経験や実際に滑走試 験を行った滑走者の主観に頼っているのが現状であ り，多くの時間とコストがかかっている．その原因の 一つとしてはスキー板の形状や機械特性が滑走性能に どのような影響を及ぼすのかが力学的に明確にされて いないことである.そこで，スキーヤの特性，スキー 板の特性および雪面の特性が滑走性能に及ぼす影響を 力学的に考慮することのできる設計法が提案されれば 設計開発を行う上で有用であると考え, 著者の一人は 文献 ( 1 )に示すスキー操作を考慮したスキー板の設計 法を提案している。この設計法では，スキー板の曲げ 変形を考慮したスキーターンのシミュレーションが基 となっている(2).このような, スキー板の曲げ変形を 考虑したスキーターンのシミュレーションを行う場 合，スキー板の機械特性(弾性パラメー夕) は重要とな る.しかしながら, スキー板は金属のような単一材料

* 原稿受付 2003 年 5 月 12 日.

*1 正員, 中部大学工学部 (画 487-8501 春日井市松本町 1200).

$* 2$ 学生員, 中部大学大学院生.

*3 正員, 中部大学工学部.

E-mail : hosokawa@isc.chubu.ac.jp
とは異なり異方性を有する複合材料が積層されている ため, 弾性パラメー夕を決定するのは非常に難しい. 近年, 振動特性を利用した弾性パラメータの同定法

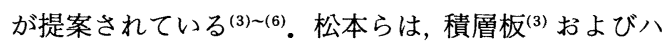
ニカムサンドウィッチ板(4) の弾性パラメータを同定 し, 著者の一人と松本は, FRP 積層円筒(5) および FRP 積層偏平シェル(6) の弾性パラメータを同定した. 上記の例はすべて同定対象が基本的な構造部材であ り，実際の製品に適用した例は著者の知る限り報告さ れていない.

本研究では, スキー板の固有振動数と振動モードを 用いて, 有限要素法による固有値解析の結果からスキ 一板の弾性パラメータを求める同定法を提案する. 次 に，この同定法のスキー板への適用性を明らかにする ため, 同定対象のスキー板と異なる特性を有するスキ 一板の弾性パラメータを初期值として同定を行う.さ らに, 同定された弾性パラメータを用いて計算された スキー板の長手方向の曲げ剛性分布およびねじり剛性 分布により同定法の適用性を検討する.

\section{2. 同定手法}

提案する同定手法は，主に有限要素法と逆問題解析 法から成る. 有限要素法による固有値解析では不均質 
な構造物に対応したソリッド要素を用いて解析できる ようにモデル化を行っている. また逆問題解析法につ いては感度解析法を用いている。

\section{$2 \cdot 1$ 同定方法 図 1 に提案する同定法の概要を} 示す. 図 1 に示すように, 提案する同定法は有限要素 解析法 (NASTRAN), 実験的モーダル解析法 (Star system), 3 D-CAD ソフト (Solid works), 逆問題解 析法から成る.まず, 伝達関数(アクセランス)を測定 するために, 図 2 に示すように同定対象のスキー板に 加速度センサを取付け, インパルスフォースハンマで 加振する. 用いた加速度センサの質量は $4.8 \mathrm{~g}$ で, 境 界条件は自由とした。この境界条件を満足させるため に, スキー板を細い糸で天井からつるした. 加振実験 より得られた伝達関数に実験的モーダル解析ソフトで ある Star system を適用し, 固有振動数を求め, これ を観測值とした。次に, 三次元 CADソフトの Solid worksによって同定対象のスキー板の幾何学形状を 描いた後, 有限要素解析ソフトである NASTRANに 取り込み, 材料特性および拘束条件を考慮して解析乇 デルを作成する，最後に作成した解析モデルと実験的 モーダル解析によって求めた固有振動数および振動モ ードを用いて逆問題解析法によりスキー板の弾性パラ メータの同定を行う.

$2 \cdot 2$ 逆問題解析法 提案する同定法では, 逆問 題解析法として感度解析法を用いる. 弾性パラメー夕 の変化量に対する固有振動数の変化量を表す感度マト リックス $A$ の各成分を次式により求める.

$$
\boldsymbol{A}_{j i}=\frac{\Delta f_{j}}{\Delta e_{i}}
$$

ここで $\Delta f_{j}$ は, $i$ 番めの弾性パラメータの変化量を $\Delta e_{i}$ としたときの $j$ 次の固有振動数の変化量である. 実験で求めた固有振動数を観測值とし, 解析による固

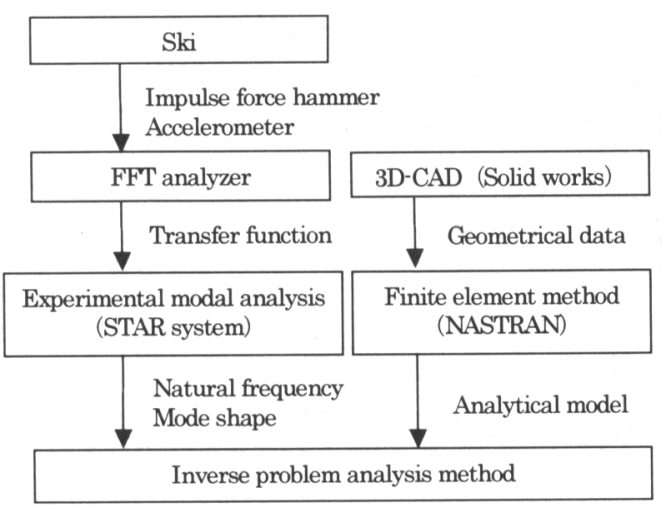

Fig. 1 Flow chart of Identification
有振動数を観測値に一致させるために必要なパラメー タの変更量ベクトル $\Delta E$ は, 感度マトリックス $\boldsymbol{A}$ の 逆マトリックス $\boldsymbol{A}^{+}$および固有振動数の観測值との差 のベクトル $\Delta \boldsymbol{F}$ を用いて，

$$
\Delta \boldsymbol{E}=\alpha \boldsymbol{A}^{+} \Delta \boldsymbol{F}
$$

として求められる。ここで， $\alpha$ は発散を防ぐための修 正係数で 1 以下の值を用いて収束計算を行う。一般 に, 感度マトリックス $\boldsymbol{A}$ は正方マトリックスではな いため, この感度マトリックス $\boldsymbol{A}$ の逆マトリックス $A^{+}$を求めるのは非常に困難である。そこで，この逆 マトリックス $\boldsymbol{A}^{+}$を次に示す特異值分解による Moore-Peneroseの一般逆マトリックスを用い, NUMPAC によって求める. $\boldsymbol{A}$ が $\mathrm{m}$ 行 $\mathrm{n}$ 列であると き適当な直交マトリックス $U, V$ を選ぶと, $A$ の逆 マトリックス $\boldsymbol{A}^{+}$を式( 3 )のように分解することがで きる。

$$
\boldsymbol{A}^{+}=\boldsymbol{V B} \boldsymbol{B}^{+} \boldsymbol{U}^{T}
$$

ここで, $\boldsymbol{U}$ および $\boldsymbol{V}$ はそれぞれ $\mathrm{m}$ 行 $\mathrm{m}$ 列, $\mathrm{n}$ 行 $\mathrm{n}$ 列のマトリックスであり, $\boldsymbol{B}^{+}$は $\mathrm{m}$ 行 $\mathrm{n}$ 列の対角マト リックス $\boldsymbol{B}$ の一般逆マトリックスである。すなわ ち,

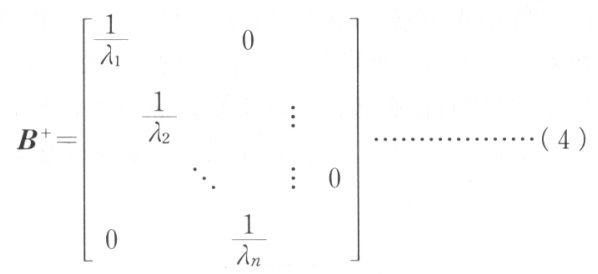

$\lambda_{k}(k=1,2, \cdots, n)$ : Singular value of $\boldsymbol{A}$

また異方性パラメータの同定過程において, 弾性パ ラメータの初期值によっては, 実験により測定した振 動モードの順序と解析による振動モードの順序が異な るという問題が生じる場合がある。これに対しては

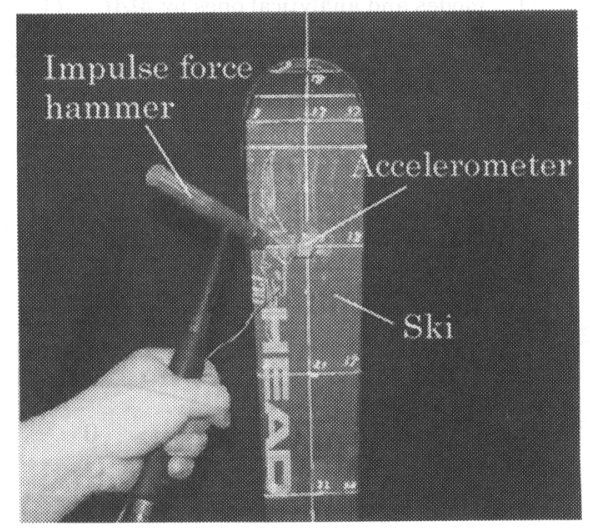

Fig. 2 Free vibration test of ski 
MAC(Modal Assurance Criterion)を用いて, 振動モ ードを対応づけることにより適切な同定を可能とす る.

本研究で提案した感度解析法の流れを図 3 に示す. まず解析モデルに入力した弾性パラメー夕の初期值を 微小変化させながら固有值解析を行い, 式(1)におけ る変化量 $\Delta e_{i}$ および $\Delta f_{j}$ を求める. 次に解析と実験 により得られた振動モードの対応づけを行った後, 感 度マトリックス $\boldsymbol{A}_{j i}$ を作成する.ささらに特異值分解を 用いて感度マトリックス $\boldsymbol{A}_{j i}$ の一般逆マトリックス $\boldsymbol{A}_{i j}$ を求め, 弾性パラメー夕の同定を行う. 最後に同 定された弾性パラメー夕を用いて固有值解析を行い, その結果得られた固有振動数が観測值に収束していれ ば同定を終了し，そうでなければ収束するまで同定解 析を繰返す。

\section{3. 同 定 結 果}

提案する同定法のスキー板への適用性を検討するた めにスキー板の弾性パラメータの同定を行った。スキ 一板は複合構造部材であり, 方向により材料特性が異 なるため, 材料特性を二次元直交異方性とした. 長手 方向と幅方向の縦弾性係数 $E_{1}, E_{2}$, およびせん断弾性 係数 $G_{12}$ の三つの弾性パラメー夕を同定した。ポアソ ン比 $\nu_{12}$ は固有振動数に及浔す影響が小さいと考え, 同定せず 0.4 と仮定した. 長手方向の縦弾性係数 $E_{1}$

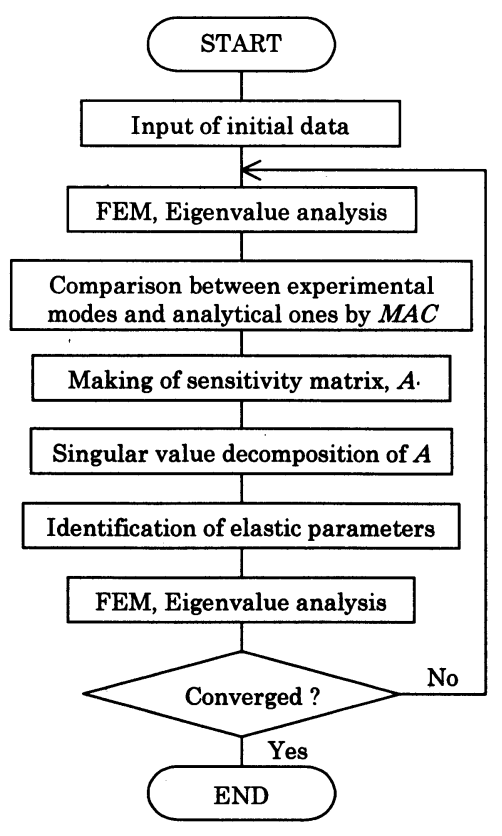

Fig. 3 Flow chart of sensitivity analysis method
の同定はスキー板の 1 次〜 5 次までの曲げの固有振動 数に注目し, また, せん断弾性係数 $G_{12}$ の同定はスキ 一板の 1 次〜 4 次までのねじれの固有振動数に注目し て,すべての固有振動数において観測値との誤差が 6\%以下になったときに上記の弾性パラメータが収束 したと判断した. 有限要素法による固有値解析におい て, 要素特性はソリッド要素とし, 加速度センサの質 量は, スキー板の質量に比べ非常に小さいので, 考慮 しないことにした。

$3 \cdot 1$ 同定用スキー板と離散化方法 提案する同 定法をカービングモデルであるスキー板 A に適用し た. 図 4 にスキー板 A の幾何学形状を示す. 伝達関 数を測定するために, スキー板 $\mathrm{A}$ を長手方向に 17 分 割, 幅方向に 3 分割した合計 53 の応答点を使用した。 加速度センサは振動の節とならない応答点の一つに取 付けた。 また, 有限要素法による固有值解析において は, スキー板 A を要素数 1328 , 節点数 2974 に分割 した，密度は実際に測定した質量を近似的に求めた体 積で割ることにより算出した $1206 \mathrm{~kg} / \mathrm{m}^{3}$ を用いた。 また, 同定を行う際に入力する弾性パラメータの初期 値は, 同定対象のスキー板とは異なる特性を有するジ ヤイアントスラロームモデルのスキー板 B あるいは Cの弾性パラメータとした。

$3 \cdot 2$ スキー板の固有振動数比較 初期値として スキー板 B の弾性パラメータを用いてスキー板 A の 弾性パラメータを同定した。この同定した弾性パラメ 一夕を用いて計算した 1 次 5 次までの曲げの固有振 動数を表 1 に, 1 次〜 4 次までのねじれの固有振動数 を表 2 に表す．また，比較のために実験的モーダル解 析法により求めたスキー板 $\mathrm{A}$ の曲げおよびねじれの 固有振動数を実験值として併せて示す.表 1 および表 2 から明らかなように曲げの固有振動数の数值計算結 果と実験結果の誤差は最大で $4.96 \%$ あり，ねじれの

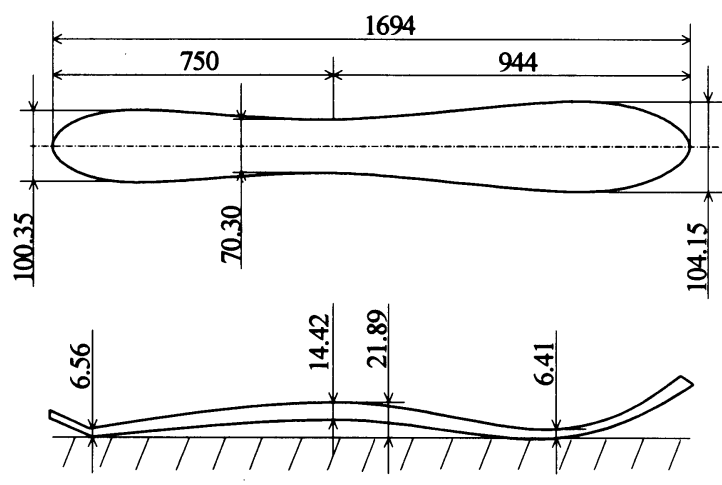

Fig. 4 Geometrical configuration of ski A 
Table 1 The bending natural frequencies estimated by the identified equivalent elastic parameters (Initial data: the equivalent elastic parameters of ski B)

\begin{tabular}{c|c|c|c}
\hline $\begin{array}{c}\text { Modal } \\
\text { order }\end{array}$ & $\begin{array}{c}\text { Numerical } \\
\text { natural } \\
\text { frequencies } \\
\text { (Hz) }\end{array}$ & $\begin{array}{c}\text { Experimental } \\
\text { natural } \\
\text { frequencies } \\
(\mathrm{Hz})\end{array}$ & Error(\%) \\
\hline 1st & 18.37 & 17.5 & 4.74 \\
\hline 2nd & 39.58 & 38.3 & 3.23 \\
\hline 3rd & 71.66 & 69.8 & 2.60 \\
\hline 4th & 114.7 & 111 & 3.23 \\
\hline 5th & 171.5 & 163 & 4.96 \\
\hline
\end{tabular}

Table 2 The twisting natural frequencies estimated by the identified equivalent elastic parameters (Initial data: the equivalent elastic parameters of ski B)

\begin{tabular}{c|c|c|c}
\hline $\begin{array}{c}\text { Modal } \\
\text { order }\end{array}$ & $\begin{array}{c}\text { Numerical } \\
\text { natural } \\
\text { frequencies } \\
\text { (Hz) }\end{array}$ & $\begin{array}{c}\text { Experimental } \\
\text { natural } \\
\text { frequencies } \\
(\mathrm{Hz})\end{array}$ & Error(\%) \\
\hline 1st & 94.48 & 92.5 & 2.10 \\
\hline 2nd & 125.0 & 120 & 4.00 \\
\hline 3rd & 194.6 & 191 & 1.85 \\
\hline 4th & 287.0 & 280 & 2.44 \\
\hline
\end{tabular}

Table 3 The bending natural frequencies estimated by the identified equivalent elastic parameters (Initial data: the equivalent elastic parameters of ski C)

\begin{tabular}{c|c|c|c}
\hline $\begin{array}{c}\text { Modal } \\
\text { order }\end{array}$ & $\begin{array}{c}\text { Numerical } \\
\text { natural } \\
\text { frequencies } \\
(\mathrm{Hz})\end{array}$ & $\begin{array}{c}\text { Experimental } \\
\text { natural } \\
\text { frequencies } \\
(\mathrm{Hz})\end{array}$ & Error(\%) \\
\hline 1st & 18.33 & 17.5 & 4.53 \\
\hline 2nd & 39.89 & 38.3 & 3.99 \\
\hline 3rd & 72.73 & 69.8 & 4.03 \\
\hline 4th & 116.3 & 111 & 4.56 \\
\hline 5th & 171.8 & 163 & 5.12 \\
\hline
\end{tabular}

Table 4 The twisting natural frequencies estimated by the identified equivalent elastic parameters (Initial data: the equivalent elastic parameters of ski C)

\begin{tabular}{c|c|c|c}
\hline $\begin{array}{c}\text { Modal } \\
\text { order }\end{array}$ & $\begin{array}{c}\text { Numerical } \\
\text { natural } \\
\text { frequencies } \\
(\mathrm{Hz})\end{array}$ & $\begin{array}{c}\text { Experimental } \\
\text { natural } \\
\text { frequencies } \\
(\mathrm{Hz})\end{array}$ & Error(\%) \\
\hline 1st & 94.9 & 92.5 & 2.53 \\
\hline 2nd & 123.5 & 120 & 2.83 \\
\hline 3rd & 193.0 & 191 & 1.04 \\
\hline 4th & 285.9 & 280 & 2.06 \\
\hline
\end{tabular}

固有振動数の数值計算結果と実験結果の誤差も最大で $4.00 \%$ とすべて収束判定の誤差範囲 6\%以下に収まっ ている.

次に, 初期值としてスキー板 C の弾性パラメータを 用いてスキー板 A の弾性パラメータを同定した.こ の同定した弾性パラメータを用いて計算した 1 次〜 5 次までの曲げの固有振動数を表 3 に, 1 次〜 4 次まで のねじれの固有振動数を表 4 に表す.また，比較のた めに実験的モーダル解析法により求めたスキー板 $\mathrm{A}$ の曲げおよびねじれの固有振動数を実験值として併せ て示す。表 3 および表 4 から明らかなように曲げの固 有振動数の数値計算結果と実験結果の誤差は最大で $5.12 \%$ であり，ねじれの固有振動数の数值計算結果と 実験結果の誤差も最大で $2.83 \%$ とずて収束判定の 誤差範囲 6\%以下に収まっている，また，本論文では 示していないが, 振動モードも大変良い一致を示して いる.

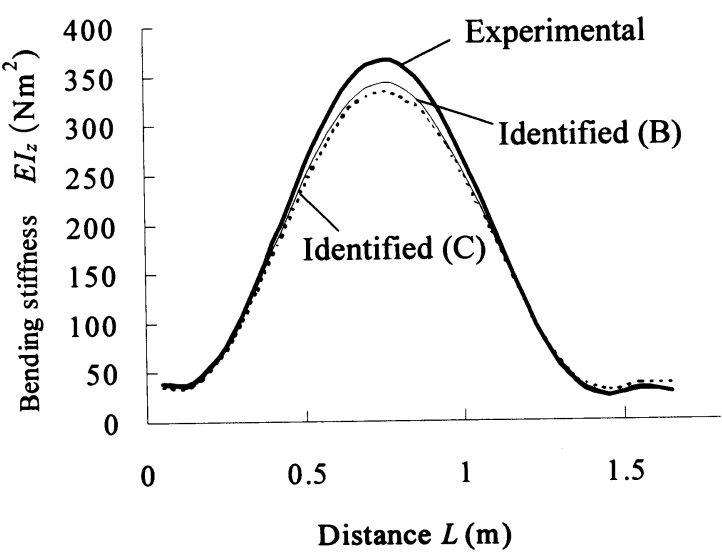

Fig. 5 Bending stiffness in logitudinal of ski A

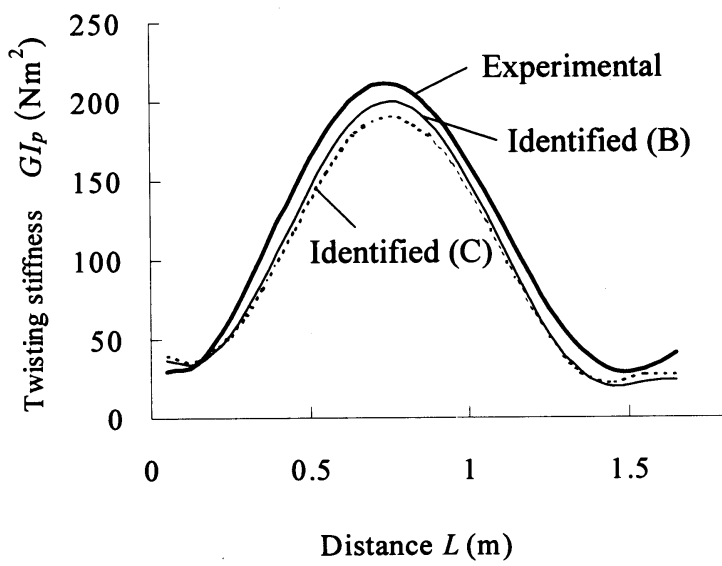

Fig. 6 Twisting stiffness in longitudinal of ski A 

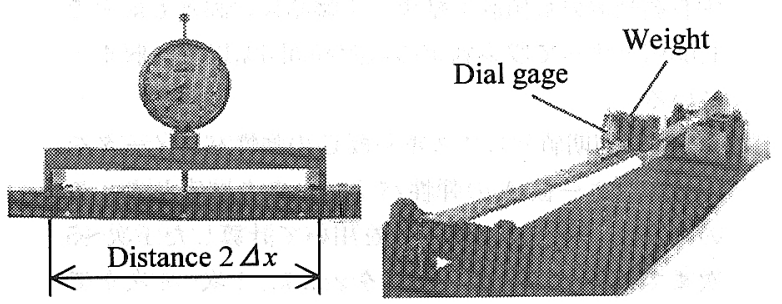

Fig. 7 Bending experimentation

\section{$3 \cdot 3$ スキ一板の長手方向の曲け剛性分布比較}

図 5 にスキー板 A の長手方向の曲げ涚性分布を表す。 図中の太い実線は静的な曲げ実験により求めた長手方 向の曲げ剛性分布を示す。この曲げ剛性分布は，図 7 に示す実験装置を用い，曲げモーメントと曲率半径を 考慮して求めた(7). 図中の細い実線は, 初期值として スキー板 B の弾性パラメータを用いて同定した弾性 パラメータより求めたスキー板 $\mathrm{A}$ の長手方向の曲げ 剛性分布を示す。同様に, 図中の点線は, 初期值とし てスキー板 C の弾性パラメータを用いて同定した弾 性パラメータより求めたスキー板 Aの長手方向の曲 け゚剛性分布を表す。図 5 より, 曲げ剛性分布の数值計 算結果と実験結果はシューセンタ付近で䛠差が多少大 きいが，最大誤差は $5 \%$ 以下であり良い一致を示して いることがわかる。

\section{$3 ・ 4$ スキ一板の長手方向のねじり剛性分布比較}

図6にスキー板 $\mathrm{A}$ の長手方向の水じり剛性分布を表 す。図中の太い実線は対じり試験により求めた長手方 向のねじり剛性分布を示す。このねじり剛性分布は図 8 に示す実験装置を用い, ねじりモーメントとねじり 角を考慮して求めた (7)。図中の細い実線は, 初期值と してスキー板 B の弾性パラメータを用いて同定した 弾性パラメータより求めたスキー板 A の長手方向の ねじり剛性分布を示す。同様に, 図中の点線は, 初期 值としてスキー板Cの弾性パラメータを用いて同定 した弾性パラメータより求めたスキー板 $\mathrm{A}$ の長手方 向のねじり剛性分布を示す。図 6 よりねひじり剛性分 布の数值計算結果は実験結果に比べて低い結果となつ たが最大誤差は 10\%以下であり良い結果が得られた と言える。

\section{4. 結 論}

スキー板の振動特性を利用したスキー板の弾性パラ

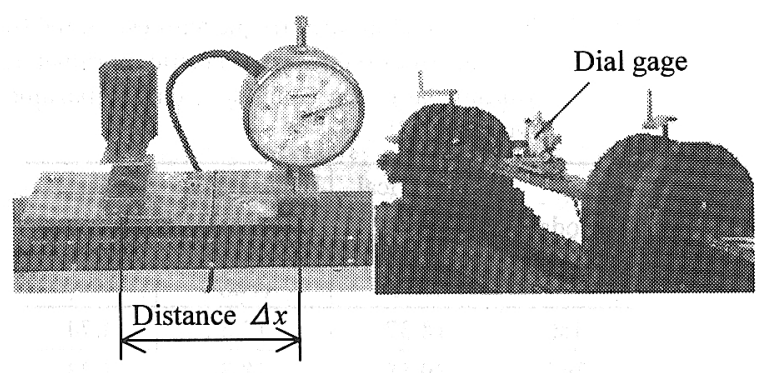

Fig. 8 Twisting experimentation

メータの同定法を提案した。提案した同定法の適用性 明らかにするために初期值として同定詨象のスキー 板とは異なる特性を有する 2 本のスキ一板の弾性パラ メータを用いて同定を行った。その結果, これら同定 された弾性パラメータを朋いて求めた曲げおよびねじ れの固有振動数の数值計算結果と実験結果は良く一致 することが明らかとなった。ささらに、これら同定され た弾性パラメータを用いてスキー板の長手方向の曲げ 剛性分布およびねじり剛性分布をそれぞれ求めた。曲 げ剛性分布およびねじり剛性分布の数值計算結果と実 際に測定した結果は良い一致を示し，提案した同定法 は精度の良いスキー板の弾性パラメータの同定を可能 とすることが明らかとなった。

\section{文献}

（1）河合茂博・加藤辟介・坂田敏行，与元られたスキーター ン特性を有するスキー板の設計法，設計工学， 38-3 (2003), 141-148.

(2) Sakata, T. and Ito, T., Simulation of ski turn, The Engineering of Sport (Proc. 2 nd Int. Conf. Eng. Sports), (1998), 361-368.

（3）松本金矢・座古勝・古野雅美, 有限要紫法固有值解析を 利用した異種積層複合材料の異方性パラメータの同定法, 機論, 62-596, C (1996), 95-100.

(4) 松本金矢・座古勝・古野雅美・藤田知正，八二カムサン ドウィッチ板の等価弾性パラメータ同定逆問題, 機論, 63-611, C (1997), 2256-2261.

(5) Hosokawa, K. and Matsumoto, K., Identification of Elastic Parameter for Laminated Circular Cylindrical Shells (Comparison of Numerical and Experimental Results), JSME Int., J., 45-1 (2002), 26-31.

(6) Hosokawa, K. and Matsumoto, K., Identification of Elastic Parameter for Laminated Shallow Cylindrical Shells (Comparison of Numerical and Experimental Results), Proc. 10th U. S.-Japan Conf. Compos. Mater., (2002), 551-559.

（7）坂田敏行・森下武志，スキー板の機械特性に関する研究， 中部大学工学部紀要, 27 (1991); 19-26. 